\title{
Economics of hail protection net installation in super intensive apple orchards
}

\author{
Viktor Szabó \\ Bold Agro Kft., Derecske, \\ szabo.viktor@boldagro.hu
}

SUMMARY

The main objective of this study was to determine and organize beneficial and detrimental effects of hail protection nets, and as far as possible to quantify their economic impact. The main factors were determined, through which hail protection nets can affect the costs and incomes of the production, and as their sum the economic result. Considering these factors together with the investment cost and the annual maintenance costs allows the economic evaluation of purchasing of hail protection nets. The analysis was carried out using a deterministic simulation model based on primary data collection from apple producing businesses. Installing hail protection nets as additional technological elements of intensive apple orchards can be concluded by all means as an economic investment - trough their protective effect. However, to achieve really favourable economic indicators, definitely bigger tree height is needed making possible the realisation of around $8.0 \mathrm{t}$ ha ${ }^{-1}$ extra yield. The main root of this phenomena are obviously the extremely high investment costs of hail protection nets, which result in a large mass of fixed costs during the production period. Therefore the basic economic interest is reaching higher yields and thereby higher profits per unit area.

Keywords: apple, economic efficiency, hail protection net, super intensive apple orchards

\section{ÖSSZEFOGLALÁS}

A dolgozat fö célkitüzése a jéghálók elönyös és hátrányos hatásainak az összegyüjtése és rendszerezése, valamint lehetöség szerint a gazdasági kihatásuk számszerüsitése. Meghatározásra kerül, hogy a jégháló milyen tényezökön keresztül gyakorol hatást a gazdálkodás költségeire és bevételeire, ezek összességeként eredményére. Mindezekhez hozzászámitva a jéghálók beruházási költségeit és éves fenntartási költségeit, értékelhetö a jégháló létesitésének gazdaságossága. Az elemzést termelö vállalkozásoknál lefolytatott primer adatgyüjtésre alapozott determinisztikus szimulációs modell alkalmazásával végeztem. Megállapitható, hogy a jégháló mint egy intenzív ültetvény kiegészitö technológiai eleme - védelmi hatásai révén - mindenképpen gazdaságos beruházásnak tekinthetö, de az igazán kedvezö gazdaságossági mutatók eléréséhez feltétlenül szükség van a nagyobb famagasság megvalósitására és az ezáltal elérhető mintegy 8,0 t/ha-os többlettermés realizálására. Ennek oka nyilvánvalóan arra vezethetö vissza, hogy a jégháló nagyon drága beruházás, amely egy nagy fix költségtömeget eredményez a gazdálkodásban, ezért alapvetö gazdasági érdekünk az, hogy egységnyi területröl minél nagyobb hozamokat, és ezáltal minél nagyobb nyereséget hozzunk le.

Kulcsszavak: alma, gazdaságosság, jégháló, szuperintenzív almaültetvény

\section{INTRODUCTION}

The gross production value of the Hungarian agriculture in recent years has been between 2000 2200 billion HUF. Crop production and horticulture have higher weight in the production structure opposed to animal husbandry with a proportion of $60-65 \%$ (KSH 2013).

Fruit production occupies a prominent role in the Hungarian agriculture, as evidenced by the significant number of personnel and fixed assets worth of billions, and it responds for $8-10 \%$ of the gross production value of crop production (Z. Kiss 2003). Domestic fruit production sites have been constantly decreasing; instead of the 41000 hectares at the millennium nowadays are merely 26000 hectares apple orchards in Hungary. Due to the extremely heterogeneous quality and poor crop safety of the orchards, the annual yield varies between 300 and 800 thousand tons, and the profitability is critical for a significant part of apple producing businesses (Fruitveb 2013).

In the resent years, the fruit sector has been experiencing falling or stagnating prices, more and more hectic changes in sales security forcing the producing businesses to provide higher performance in order to profitable fruit production (Lakner and Apáti 2010).
Apáti and Gonda (2013) considers that in the future - as a result of both Hungarian and international development trends - only the apple orchards and apple producing businesses will be competitive, which can reach almost every year $40-60 \mathrm{t} \mathrm{ha}^{-1}$ yields and 80 $90 \%$ dessert apple ratio. In their view, for competitive production among others the following factors are needed: high plant densities (from 3000-4000 trees ha ${ }^{-1}$ ), intensive farming system, production of consistently high yield capable, well-colouring, well storable, transportable and long shelf life, modern varieties, used of advanced technological elements, availability of irrigation throughout the whole orchard, furthermore use of hail safety system on more than $50 \%$ of the production area.

In my opinion - in agreement with Apáti and Gonda (2013) above described view - the increase of profitability and efficiency of apple production is possible by increasing the intensity, a key element of which is the installation of hail protection system. The significance of this is the protection against ice damage and sunburn damage, and the creation of a favourable microclimate for achieving high specific yields (Apáti 2012) and providing a safe support system for maintaining high yields. 
The benefits of hail protection net appear not only for the apple farm. In countries with much more organised production and sales than Hungary (Germany, Austria, Italy, the Netherlands, etc.) very often PSCs promote and encourage the purchase of hail protection nets. The reason of this is, that only with hail protection nets can be orchards established with high crop safety, and stable sales and market organisation can be based only on every year balanced quantity and quality providing orchards. Therefore sales organisations are interested in establishment of hail protection nets. However, hail protection nets have naturally some disadvantages as well (deterioration of colouring, decrease in luminance, etc.), which may also influence the result of farming.

In Hungary, a greater establishment of hail protection net began about 2007-2008, when the possibility of support of hail protection net installation was first entered into the plantations supports. Since then, about 1000-1500 hectares apple orchards have been covered with hail protection nets, which is still a very low proportion compared to the total 26000 hectares total apple producing area. The opinion of Hungarian apple producers is still divided, whether the use of hail protection nets under the Hungarian circumstances rather a beneficial or a disadvantageous technological element is. Therefore, this study aims to define the benefits and disadvantages of hail protection nets based on the body of literature and own primer data collection, as well to analyse with economic calculations the justification of its establishing. Hail protection nets have - because of the above mentioned - a very wideranging economic impact. They protect not only the harvest and through that the revenue, but their role prevails in the whole management process (production, postharvest, marketing).

The main objective of this study was to determine and organize beneficial and detrimental effects of hail protection nets, and as far as possible to quantify their economic impact. I try to summarise, through which factors hail protection nets affect the costs and revenue of the production, and as their sum the economic result. Considering these factors together with the investment cost and the annual maintenance costs allows the economic evaluation of purchasing of hail protection nets.

\section{MATERIAL AND METHODS}

The analysis methodology used for achieving the objectives was the methodological tools of cost-benefit analysis and investment analysis. There are two main methods of investment analysis: static and dynamic analyses. Dynamic methods, which differ from static methods as they consider the time value of money, provide much more professional, accurate and precise result (Warren 1982, Graham and Harvey 2001, Illés 2002). Several indicators are available for dynamic investment analysis, from which the NPV (Net Present Value), DPP (Discounted Payback Period), and the IRR (internal rate of Return) were used in this study (Brealey et al. 2006, Szücs and Szőllösi 2008).

The central element of data processing is the simulation modelling based mostly on the primary data collection in apple producing businesses, focusing on the natural inputs and yields related to the installation and maintenance of hail protection nets, and partly on secondary data collection.

To perform the tests, similarly to the researches of Szőllősi (2008) Apáti (2009), a deterministic simulation model was created with input data of technological factors on the one hand, and economic parameters on the other hand. This model was suitable for the complex cost-benefit analysis, the investment analysis and the sensitivity studies related to the establishment and maintenance of hail protection nets, whereby the impact of changes in input and output prices, yields, investment and maintenance costs and supports on economic result and profitability can be evaluated.

Considering the boundary conditions of the calculations, it is important, that current prices were used in the investment analysis, i.e. inflation was calculated neither in the output, nor in the input markets. This was because hardly any forecasts can be made 15 years in advance on the changes of input and output prices, and the future trends are hardly predictable from past tendencies. Input prices are only partly responsible for the changes of production costs, however, the continuous innovation on the input markets, the introduction of new materials and machines, constantly advancing the production technology, have a significant effect on production costs as well. The impact of these changes on the costs is also difficult to estimate. Thus, the presumption was that on the input and output markets will be a long-term price changes, but the income position of production will be at the current level considered in the calculations, and will not change significantly.

The amortisation costs obviously could not be counted among the expenditures, however, their 'tax shield effect' was not considered as well, as the analysis was made with pre-tax income categories. The level of calculative interest rate (r) in the calculations was $6 \%$, corresponding to the average money market interest rates of the past five years (bank deposit). The average life span of the investments was considered 15 years. The analyses were based on the most likely expected realistic scenario. The hidden uncertainty of management and calculations were considered in sensitivity analyses.

Another important boundary condition was that the model assumed a super intensive apple orchard, cultivated on high quality and being in good condition. This presumed orchard had $3.5 \mathrm{~m}$ tree height, $3.25 \times 1.0 \mathrm{~m}$ spacing (3076 tree ha ${ }^{-1}$ density), hail protection net system with concrete columns, Knipp-tree as planting material and around a yield of $60 \mathrm{tha}^{-1}$ in the long-term average. $95 \%$ of the produced apples are dessert quality.

Good production level and high technological standard of discipline were also presumed in the model. The calculations did not apply to the national average, but a modern orchard with high production level. The prices and unit costs of inputs used (materials, manual labour, machine works) reflect the price levels of the years 2013-2014, material prices were considered without VAT, but manual labour costs with contributions. The yields, the yield quality and the selling prices were represented with a longer term -5 years - average.

For economic analysis it is important to fix the benchmark. In this analysis, the basis of the correlation was, that what would happen in the same orchard (spacing: $3.25 \times 1.0 \mathrm{~m}$, planting material: Knipp-tree 
crown shape: super spindle), when a taller and more robust support system was built instead of the normal support system and the orchard was covered with hail protection net. The consequence of this approach was that under the hail protection net support system approx. half a meter higher tree height can be achieved than with normal support system, which resulted in higher yields.

The economic calculations were therefore made not for a super intensive apple orchard with hail protection nets, but only for the hail protection net system as an additional technological element. So only the effects caused exclusively by the installation of hail protection net were considered.

\section{RESULTS AND DISCUSSION}

Technological and economic benefits of hail protection nets

Table 1 shows the positive technological and economic effects of hail protection net systems. The expert estimates were based on data collection from producers, own measurement results and production experience, as well on the literature. The very indirect and spill over effects (long-term implications for the alternation or the fruit tree cancer) were not included in the calculation, because it is difficult to measure and can only be measured or estimated on very long-term (such long-term experience in Hungary are not yet available), as well as a strong dependence of the variety. The analysis also did not take into account the impacts of hail protection nets during the postharvest processes on unit costs of storage, sorting and packaging, as well as the effect on storage losses, because the calculations were made for sale immediately after harvest. However, the impact of a more consistent quality on the postharvest processes is not negligible.

\section{Technological and economic disadvantages of hail} protection nets

Table 2, similarly to the benefits, shows the negative effects of hail protection nets. As above mentioned in the literature review, in some production areas the following are adduced as serious disadvantage of hail protection nets:

- In some vintages and in case of 'harder' colouring varieties it might harm the colouration, but in production areas with high light intensity it seems to be less problematic.

- It might reduce fruit size and harvest, causing serious problems primarily in production areas with low light intensity.

The advantages of hail protection nets and their estimated effect on the production

\begin{tabular}{cl}
\hline Factor & \multicolumn{1}{c}{ Estimated impact } \\
\hline Protects against hail (quantitative loss) & $\begin{array}{l}\text { Hail firstly and significantly causes damage to the apple quality, so the effect on the yield } \\
\text { can be estimated merely of } 2 \% .\end{array}$
\end{tabular}

Protection against Sunburn (quantitative loss) Protection against Sunburn (quality loss)

Plus yields resulting from bigger tree height due to higher support system The prevention of quality losses caused by hail results in $13 \%$ higher dessert apple ratio. $50.0 \mathrm{t} \mathrm{ha}^{-1}$ yield is expected from a standard apple orchard with $3.0 \mathrm{~m}$ tree height and standard support system. Due to the higher hail protection net support system, the tree height can be increased with about $0.5 \mathrm{~m}$, which results in approx. $16 \%$ bearing surface growth. This corresponds to approx. $8.0 \mathrm{t} \mathrm{ha}^{-1}$ extra harvest. This additional result has been confirmed by practical experience. (The variable costs of the additional yield due to the hail protection system were considered in the calculations.)

$1 \%$ increase in the volume of harvested crop.

In a several years of average, $4 \%$ increase was observed in the proportion of dessert apples (i.e. in case of $60.0 \mathrm{t} \mathrm{ha}^{-1}$ yield 2.4 tonnes less apple is produced for industrial purpose). In some years, this effect may be as high as $10 \%$, but in the calculations the several years of average was taken into account.

\begin{tabular}{ll}
\hline $\begin{array}{l}\text { Mitigation of heat stress and atmospheric } \\
\text { drought (impact on the harvest) }\end{array}$ & $\begin{array}{l}\text { Difficult to measure and quantify. Depending on vintage } 0.0-4.0 \mathrm{t} \text { ha }{ }^{-1} \text { yield can be } \\
\text { estimated for this reason. }\end{array}$ \\
$\begin{array}{l}\text { Mitigation of heat stress and atmospheric } \\
\text { drought (impact on quality) }\end{array}$ & $\begin{array}{l}\text { It cannot be estimated, and probably only during long-term storage could affect the removal } \\
\text { quality. }\end{array}$ \\
\hline $\begin{array}{l}\text { Protection against spring frost } \\
\text { (impact on the quantity) }\end{array}$ & $\begin{array}{l}\text { Hail protection nets are able to minimally }\left(1.0-1.5^{\circ} \mathrm{C}\right) \text { increase the area temperature in case } \\
\text { of eradiating frost, which means only in a small number of cases saving the harvest from } \\
\text { frost damage. Several years on average } 0.5-1.0 \mathrm{t} \mathrm{ha}^{-1} \text { extra yields can be attributed to this } \\
\text { effect. }\end{array}$ \\
\hline $\begin{array}{l}\text { Pesticides dry slower and due to less air movement due coverage is better, so overall more } \\
\text { effective pest control can be experienced, resulting in circa } 2 \% \text { higher dessert apple } \\
\text { proportion. }\end{array}$ \\
$\begin{array}{ll}\text { It hinders the flight of the codling moth and the cockchafer, making their copulation harder. } \\
\text { However, it cannot reduce the number of sprayings; therefore no significant impact was } \\
\text { considered. }\end{array}$ \\
$\begin{array}{l}\text { Hail protection nets significantly reduce wind damage, moreover, in extreme cases, during } \\
\text { an extraordinary strong storm can save the whole orchard, but these possible effects cannot } \\
\text { be considered among the factors impacting the production. }\end{array}$
\end{tabular}

Source: own calculations 
The disadvantages of hail protection nets and their estimated effect on the production

\begin{tabular}{ll}
\hline \multicolumn{1}{c}{ Factor } & \multicolumn{1}{c}{ Estimated impact } \\
\hline Less flower, more powerful shedding. & $\begin{array}{l}\text { Based on the current national experience, a decrease in bloom substantially affecting the } \\
\text { harvest is unlikely. These in certain vintages occurring effect could be offset with } \\
\text { technological interventions (chemical os mechanical). }\end{array}$ \\
\hline Stronger sprout initiation & $\begin{array}{l}\text { The pruning costs are by about 10\% increased due to formation of little more, but primarily } \\
\text { stronger sprouts. }\end{array}$ \\
\hline Hinders the work of pollinating bees & $\begin{array}{l}\text { Hail protection nets theoretically disrupt the orientation of bees and the closed nets prevent } \\
\text { their over flight, hence bee colonies must be placed in the orchards. Thus not any } \\
\text { fecundation problem can be observed. However, this intervention has an extra cost of }\end{array}$ \\
\hline $\begin{array}{l}\text { In wetter periods, the more humid } \\
\text { microclimate enhances the fungal infection }\end{array}$ & $\begin{array}{l}\text { No additional plant protection costs have been experienced, there have been no extra spray } \\
\text { needed. Chemicals are 'floating' in the orchard even 4-5 hours after the spraying, they dry } \\
\text { more slowly and therefore show increased drug efficiency. }\end{array}$ \\
\hline $\begin{array}{l}\text { Prevent the rodent-thinning by birds of prey } \\
\text { This effect is strongly observed, resulting in higher cost of the rodent control and } \\
\text { greater loss of trees. The combined additional cost of all these factors can be estimated } \\
\text { ca. 70 000 HUF ha }{ }^{-1} \text { (related substance use and manual labour). }\end{array}$ \\
\hline $\begin{array}{l}\text { Puddles and pools do not dry but also spread, hence machines consume more fuel on damp } \\
\text { ground; approx. 10\% increase in fuel consumption can be estimated. }\end{array}$
\end{tabular}

Source: own calculations

The above described drawbacks was not considered in the analysis, because under Hungarian climatic conditions (based on harvests of foreign apple producing areas with similar climate) hail protection nets are not likely to have such an effect. They are rather likely to somehow improve fruit size and harvest due to reducing weather stresses. The fruit colouring problems were also not considered, because of the presumption of varieties under hail protection nets (e.g. Golden Reinders, Red Delicious and Gala varieties, possibly Red Idared or Red Jonaprince), which will be nearly $100 \%$ coloured even under black nets. In case of these varieties only the colour intensity or depth could be below the standard. However, in case of Golden varieties, colouring does not mean any problem, moreover, the moderation or disappearance of red blush (which is not liked in Hungarian markets) some favourable effect can be observed.

\section{Economics of installing hail protection nets}

Dynamic investment analysis indicators (NPV, DPP, PI, IRR) were used for assessing the profitability of hail protection nets. The following factors must be determined in order to calculate them:

- the investment costs of the hail protection system $\left(\mathrm{C}_{0}\right)$,

- the annual maintenance and operational costs of hail protection nets as a technological element,

- the direct and indirect effects of the nets on the costs and revenues of apple production.

Using the above described factors, the effects of using hail protection nets as a supplementary, additional technological element on the farming costs and revenues become quantifiable compared to the same orchard with standard support system and no coverage. So only the effects were taken into account, which can be attributed only to the presence of hail protection nets, and would not be if the nets had not been installed.

\section{Investment costs}

The economic calculations were made for the hail protection net system of a super intensive apple orchard with $3.25 \times 1.0 \mathrm{~m}$ spacing, and Knipp-trees as planting material. The support system includes $4.0 \mathrm{~m}$ high concrete pillars with black nets, which means higher investment costs and several years on average lower maintenance costs than in case of support systems with wooden columns. The main reason of that is, that the life of the concrete columns correspond to two plantation lifetime (approx. 30 years), and the black net can serve an entire plantation. The intermediate columns are $9.0 \times 11.0 \mathrm{~cm}$ thick and $4.5 \mathrm{~m}$ long, the columns at the ends are $11.0 \times 13.0 \mathrm{~cm}$ thick and $4.7 \mathrm{~m}$ long. The spacing between the intermediate columns is 10 meters. The system provides both longitudinal $(3.5 \mathrm{~mm}$ thick steel wire) and transverse (3.0 mm wire) tension for greater capacity. They are fixed to anchors with $40.0 \mathrm{~cm}$ diameter and $1.0 \mathrm{~m}$ shaft length.

Table 3 shows, that the investment costs of a hail protection net system is closely 4.5 million HUF ha- ${ }^{-1}$. $80 \%$ of this is made up by material costs and the manual labour and machine work costs of the construction respond for the remaining $20 \%$.

Among the material cost of the system is the largest item the cost of the concrete columns, they mean about 1.5 million HUF expenditure due to their ca. $4000 \mathrm{HUF}$ piece $^{-1}$ unit price. Only the purchasing cost of the net is about 1.1-1.2 million HUF. Among the costs of other materials, the anchors are the largest item, but here will also be charged in the following: column cap, wire ropes, wirings, chains, load binders, plaques, staples and other small accessories.

It is an important aspect in terms of judging the investment costs, that if establishing a new orchard, where a standard support system would be needed anyway, the installation of a hail protection net system saves the investment costs of the standard support system. Thus, the additional costs of hail protection nets compared to the standard support systems (i.e. pure investment costs) is about 3.2 million HUF ha- ${ }^{-1}$. In case of installing hail protection nets in existing orchards, this quasi cost saving effect does not appear, however, this calculation presumes a newly planted orchard. 


\section{Annual maintenance costs, operating expenses}

Hail protection net systems do not have substantial operating costs. The annual maintenance works are essentially limited to the spring close and autumn open of the hail protection net (Table 4).

The spring close of the net will take place shortly before flowering. This work requires about 1.5 machine work hours (tractor) and 10-15 manual labour work hours. The autumn open of the net, whereby the net is being disconnected and coiled to the longitudinal tension wires, requires almost twice as much manual labour and three times as much machine work than the spring works. The total cost of these operations is so approximately 85 thousand HUF ha ${ }^{-1}$. In addition, the maintenance of hail protection nets has no other substantial costs during the entire life of the plantation. Only the not really high costs of periodic inspection and maintenance of the system could still arise. With all these together the annual maintenance of hail protection net system results in 90-100 thousand HUF ha-1 additional costs in comparison to a standard support system.

Table 3.

Investment costs of hail protection net system with concrete columns support system divided by the main cost items

\begin{tabular}{lr}
\hline \multicolumn{1}{c}{ Description } & Cost (thousand HUF ha $^{-1}$ ) \\
\hline Support columns & 1520 \\
Net & 1110 \\
Other materials & 935 \\
Total material costs & 3565 \\
Total labour costs (machine works and manual labour) & 780 \\
The total investment cost of hail protection net system & 4345 \\
Additional cost savings & 1135 \\
Pure investment costs of hail protection net system & 3210 \\
\hline
\end{tabular}

Source: own calculations

The annual maintenance costs of the hail protection net system

\begin{tabular}{|c|c|}
\hline Description & Cost $\left(\right.$ HUF ha $\left.^{-1}\right)$ \\
\hline Costs of spring close & 26435 \\
\hline from which: manual labour & 20870 \\
\hline machine work & 5565 \\
\hline Costs of autumn open & 58435 \\
\hline from which: manual labour & 41740 \\
\hline machine work & 16695 \\
\hline Inspection, maintenance & 10000 \\
\hline Total annual maintenance costs & 94870 \\
\hline
\end{tabular}

Source: own data collection

The of the hail protection nets on the production costs and revenues

For assessing the profitability of hail protection nets, its impact on the apple production costs and revenues is needed to be known, in addition to the maintenance costs. The estimated monetary extent of these effects was determined based on the factors listed in Table 1 and Table 2.

Table 5 summarises the monetary expressible impacts of hail protection nets. As boundary condition of the calculations, $68.83 \mathrm{HUF} \mathrm{kg}^{-1}$ dessert apple selling price and $22.00 \mathrm{HUF} \mathrm{kg}^{-1}$ industrial apple selling price were assumed. In addition, it must be assumed that an orchard with $3.25 \times 1.00 \mathrm{~m}$ spacing and standard support system, through which tree height cannot exceed $3.0 \mathrm{~m}$ can provide an average yield of $50.0 \mathrm{t} \mathrm{ha}^{-1}$ with less than $75 \%$ dessert apple ratio because of various quality losses (hail damage, sunburn, etc.). Further, it constitutes the benchmark.

According to my calculations, $11.5 \mathrm{t} \mathrm{ha}^{-1}$ extra yield can be achieved in orchards with hail protection nets, due to higher trees, more favourable microclimate, prevention or significant mitigation of hail damage and sunburn and slight mitigation of frost damage. These effects have been already detailed in Table 5, and need no more explanation. $95 \%$ of the extra $11.5 \mathrm{t} \mathrm{ha}^{-1}$ yield is dessert apple, the additional $5 \%$ is cider apple, which results in 764618 HUF extra revenue per hectares.

Moreover, another source of revenue growth is the 19 percentage point improvement in dessert apple ratio. $13 \%$ of this comes from hail prevention, $4 \%$ from sunburn prevention, while $2 \%$ from the more effective plant protection. Mutatis mutandis, this quality improvement has to be calculated only for the initial $50.0 \mathrm{t} \mathrm{ha}^{-1}$ yield (and multiplied by the difference between the dessert and cider apple prices), because the $11.5 \mathrm{t} \mathrm{ha}^{-1}$ extra yield due to the hail protection net have already been calculated with $95 \%$ dessert apple ratio achievable with the system.

Thus, the saved dessert ratio, i.e. the improvement in quality results in $444885 \mathrm{HUF}^{-1}$ extra revenue. Added the additional revenues achieved due to the yield increase and quality improvement, the total revenue increase was $1029503 \mathrm{HUF} \mathrm{ha}^{-1}$ due to the use of hail protection nets. 
The effects of hail protection nets on the production revenues

\begin{tabular}{|c|c|c|}
\hline Description & Value & Unit \\
\hline Sales price - dessert apple & 68.83 & HUF kg ${ }^{-1}$ \\
\hline Sales price - apple for industrial purpose & 22.00 & HUF kg ${ }^{-1}$ \\
\hline Starting yield without hail protection net system & 50.00 & $\mathrm{tha}^{-1}$ \\
\hline Extra yield due to bigger tree height & 8.00 & $\mathrm{t} \mathrm{ha}^{-1}$ \\
\hline Extra yield due to the favourable microclimate & 1.50 & $\mathrm{t} \mathrm{ha}^{-1}$ \\
\hline Extra yield due to the prevention of hail damage & 1.00 & $\mathrm{t} \mathrm{ha}^{-1}$ \\
\hline Extra yield due to the prevention of sunburn & 0.50 & $\mathrm{t} \mathrm{ha}^{-1}$ \\
\hline Extra yield due to the mitigation of frost damages & 0.50 & $\mathrm{tha}^{-1}$ \\
\hline Realised yield with hail protection net system & 61.50 & $\mathrm{t} \mathrm{ha}^{-1}$ \\
\hline Total extra harvest & 11.50 & $\mathrm{tha}^{-1}$ \\
\hline Dessert apple ratio from the extra harvest & 95.00 & $\%$ \\
\hline Cider apple ratio from the extra harvest & 5.00 & $\%$ \\
\hline Extra revenue from the extra harvest & 764618 & HUF ha $^{-1}$ \\
\hline Saved dessert apple ratio (percentage points) & 19.00 & $\%$ \\
\hline Extra revenue from saved dessert apple ratio & 444885 & HUF ha ${ }^{-1}$ \\
\hline Total extra revenue due to the hail protection net: & 1209503 & HUF ha ${ }^{-1}$ \\
\hline
\end{tabular}

Source: own calculations

Table 6 shows the summarised extra costs of having a hail protection net system, increasing the production costs compared to an orchard without hail protection nets.

The opening and closing costs of hail protection nets, as well the annual inspection and maintenance costs have been previously detailed, this amount nears to 100 thousand HUF ha-1.

Naturally, the additional variable costs given in Table 6 are associated with the yield increase, which can be traced back to the increased costs of the following work operations: pruning, nutrient management, irrigation, crop management, harvesting and other minor works. The additional variable costs of extra harvest reach 19.6 HUF kg-1 , derived from above mentioned background calculations. In my opinion, some out of these costs will not substantial change with higher trees and increased yields. The unchanging costs are: costs of soil cultivation and cultivation between rows, costs of plant protection, amortization costs of the orchard and the general costs (the latter two are definitely fixed cost for the current decision problem).

The 19 percentage-point improvement in quality also will not have a substantive effect on production costs because the amount of these crops have already been considered in the initial $50.0 \mathrm{t} \mathrm{ha}^{-1}$ yield, not in dessert, but in industrial quality. This industrial quality proportion, however, still has to be harvested, and every other work operations has to be done regardless of what quality these proportion has on the trees. Substantive incremental costs due to quality improvement could only be experienced in the postharvest costs, as the storing and marketing of dessert apples is obviously more expensive, but the calculation were made for immediate sale after harvest, including the production costs, sale prices and sold yield as well.

Added the above described costs of opening and closing of hail protection nets, annual inspection and maintenance, and other extra working operations detailed in Table 6 , the total additional production costs are 415170 HUF ha $^{-1}$.

The difference between the extra revenues and the additional costs points out, that the establishing of hail protection nets increases the annual profit, more precisely, the annual cash flow by 794333 HUF. In the investment analysis, this extra profit faces the $3210000 \mathrm{HUF}^{-1}$ additional investment costs of the installation of hail protection nets $\left(\mathrm{C}_{0}\right)$, i.e. $\mathrm{C}_{0}$ has to be recovered out of this cash flow surplus. The next section details these results with static and dynamic investment analysis indicators.

The effect of hail protection nets on the production costs

\begin{tabular}{|c|c|c|}
\hline Description & Value & Unit \\
\hline Spring close of hail protection nets & 26435 & HUF ha $^{-1}$ \\
\hline Autumn open of hail protection nets & 58435 & HUF ha ${ }^{-1}$ \\
\hline Inspection, maintenance & 10000 & HUF ha ${ }^{-1}$ \\
\hline Variable costs of extra harvest & 19.6 & HUF kg ${ }^{-1}$ \\
\hline Additional variable costs of extra harvest & 225400 & HUF ha ${ }^{-1}$ \\
\hline Additional costs of pruning & 7400 & HUF ha ${ }^{-1}$ \\
\hline The cost of placing beehives & 7500 & HUF ha ${ }^{-1}$ \\
\hline Costs of rodent control and losses caused by rodents & 70000 & HUF ha $^{-1}$ \\
\hline Additional machine costs & 10000 & HUF ha ${ }^{-1}$ \\
\hline Total extra costs caused by hail protection nets: & 415170 & HUF ha ${ }^{-1}$ \\
\hline
\end{tabular}

Source: own calculations 
Investment analysis of establishing hail protection nets

Figure 1 demonstrates the major economic indicators of investing in hail protection nets for the entire lifetime of the orchard. The base case summarises the economic impacts described in the above section, i.e. 794 thousand HUF ha ${ }^{-1}$ extra cash flow faces 3210 thousand HUF ha-1 additional investment costs. The calculations were carried out for 2 scenarios, investment with $100 \%$ own resources and with $40 \%$ support intensity. The only difference between the 2 scenarios is that in the latter case only $60 \%$ of $\mathrm{C}_{0}$ was taken into account, but the curves followed the same path.

Based on the economic indicators demonstrated in Figure 1 and Table 7, it can be concluded, that the economics of hail protection nets show a very positive picture. The additional costs of hail protection net investment -3210 thousand HUF compared to orchards with standard support system - returns even in case of $100 \%$ own financing sources, as in static, as in dynamic approaches, over 5 years. With investment support, the payback period is reduced to 3 years. Every economic indicator can be considered as very positive.

Both cumulated cash flow and net present value (NPV) indicator reach very high values at the end of orchard life (15 years). The IRR of close to $24 \%$ ( $41 \%$ with investment support) can be considered a very good value. This means, that the hail protection net as a supplementary, additional technological element through its protecting effects - can be described with more favourable economic parameters, than the whole system together.

It should be pointed out that in the above calculations, the initial assumption was that because of the massive support system a $0.5 \mathrm{~m}$ taller tree height can be realized, which produces 8.0 tons per hectare surplus in production itself.

The following calculations were made not for a $4.0 \mathrm{~m}$ high hail protection system with $0.5 \mathrm{~m}$ extra tree height, but for a $3.5 \mathrm{~m}$ high hail protection net system with a tree height of $3.0 \mathrm{~m}$ - equal to the tree height of standard support systems. The substantive difference compared to the above detailed base case is, that in this case are neither $8.0 \mathrm{t} \mathrm{ha}^{-1}$ extra yields, nor additional variable costs. The initial $50.0 \mathrm{t} \mathrm{ha}^{-1}$ harvest is protected by the hail protection nets, so the 19 percentage-point quality improvement can be observed, however, the extra harvest is merely $3.5 \mathrm{t} \mathrm{ha}^{-1}$. In addition, the investment costs are about 200 thousand HUF ha ${ }^{-1}$ less because of the $0.5 \mathrm{~m}$ shorter columns. Figure 2 and Table 8 show the economic indicators for that case.

The results show significantly decreasing, but not unfavourable economic indicators. The investment payback period without support was delayed to 8-10 years, which is not very good, but still a reasonable value. The presence of investment support provides good values in this case as well.

NPV and IRR indicators can be evaluated similarly: without support acceptable, with support very favourable.

Figure 1: The cumulated cash flow and NPV of the base case investment ( $\mathrm{r}=6 \%$ ) when investing from $100 \%$ own capital and when having $40 \%$ investment support

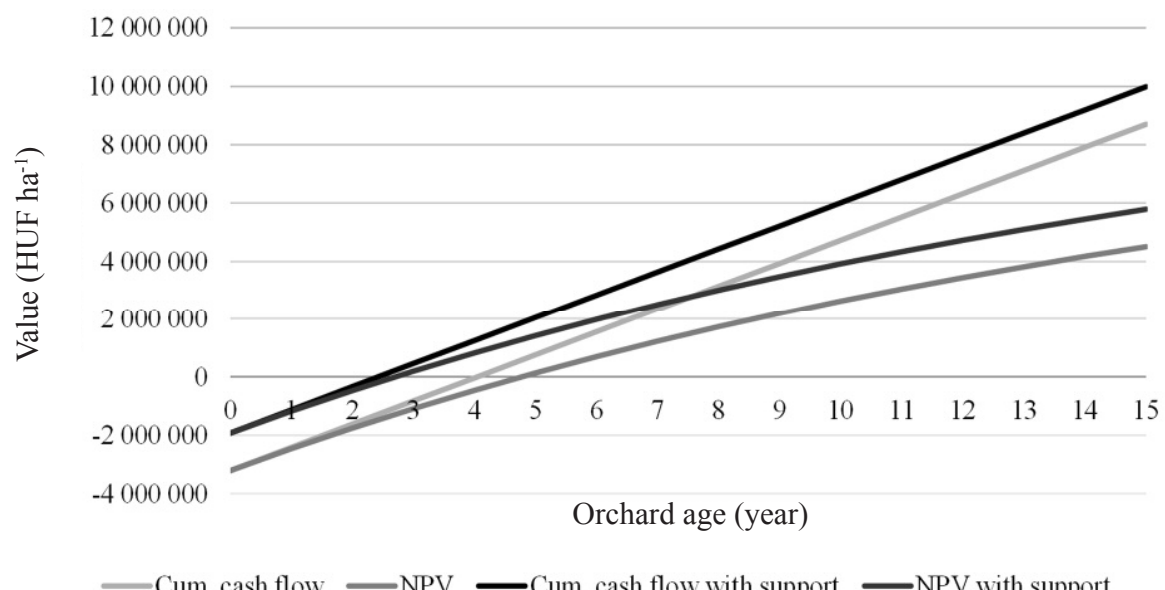

Source: own calculations

Economic indicators of the hail protection net investment in the base case

\begin{tabular}{llccc}
\hline & \multicolumn{1}{c}{ Description } & Unit & Without support & With support* \\
\hline Static indicators & Cumulative cash flow & thousand HUF ha ${ }^{-1}$ & 8705 & 5989 \\
& Static payback time & year & 3 & 5.71 \\
& Static index of return & - & 4505 & 6.19 \\
\hline Dynamic Indicators & Net present value (NPV) & thousand HUF ha ${ }^{-1}$ & 5 & 5789 \\
& Discounted payback period (DPP) & year & 2.40 & 4.01 \\
& Profitability Index (PI) & - & 23.73 & 41.00 \\
\hline
\end{tabular}

Note: $*-40 \%$ investment support, Source: own calculations 
Figure 2: The cumulative cash flow and NPV of the investment in the $2^{\text {nd }}$ scenario $(\mathrm{r}=6 \%)$ when investing from $100 \%$ own capital and when having $40 \%$ investment support

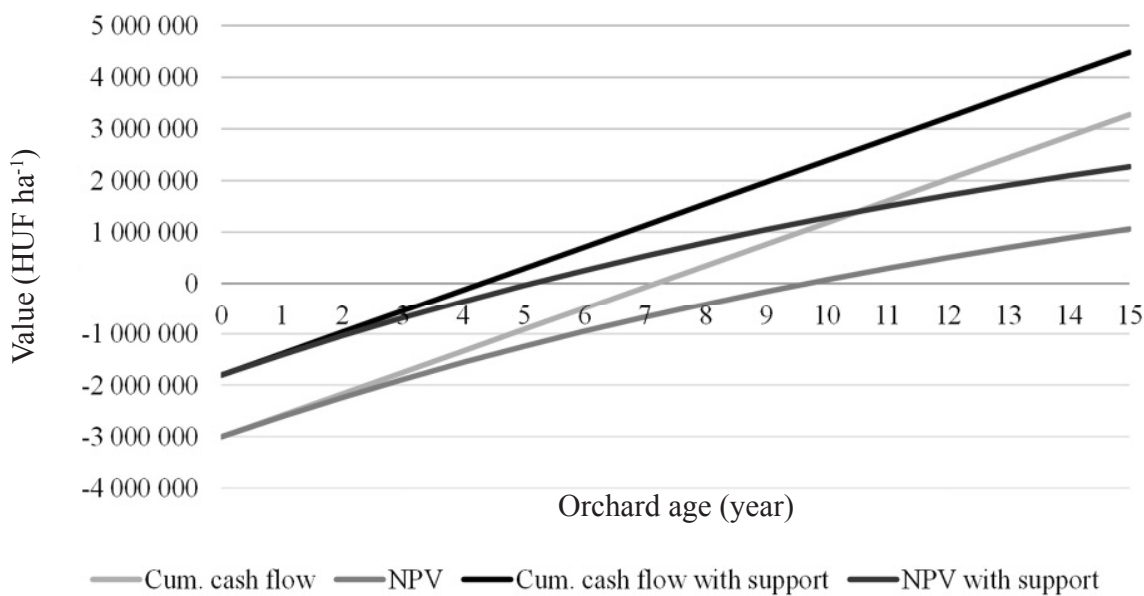

Source: own calculations

Economic indicators of the hail protection net investment in the second case

\begin{tabular}{llccc}
\hline & \multicolumn{1}{c}{ Description } & Unit & Without support & With support* \\
\hline Static indicators & Cumulative cash flow & thousand HUF ha ${ }^{-1}$ & 3278 & 4482 \\
& Static payback time & year & 8 & 2.09 \\
& Static index of return & - & 1062 & 3.48 \\
\hline Dynamic Indicators & Net present value (NPV) & thousand HUF ha & \\
& Discounted payback period (DPP) & year & 10 & 2266 \\
& Profitability Index (PI) & - & 1.35 & 6 \\
& Internal rate of return (IRR) & $\%$ & 11.03 & 2.25 \\
\end{tabular}

Note: $*-40 \%$ investment support, Source: own calculations

\section{CONCLUSIONS}

The additional costs of hail protection nets compared to the standard support systems (i.e. pure investment costs) is about 3.2 million HUF ha-1 $.95 \%$ of the extra $11.5 \mathrm{t} \mathrm{ha}^{-1}$ yield is dessert apple; the additional $5 \%$ is cider apple, which results in 764618 HUF extra revenue per hectares. Moreover, another source of revenue growth is the 19 percentage point improvement in dessert apple ratio. Thus, the saved dessert ratio, i.e. the improvement in quality results in $444885 \mathrm{HUF} \mathrm{ha}^{-1}$ extra revenue. Added the additional revenues achieved due to the yield increase and quality improvement, the total revenue increase was $1029503 \mathrm{HUF} \mathrm{ha}^{-1}$ due to the use of hail protection nets.

The costs of opening and closing of hail protection nets, annual inspection and maintenance, and other extra working operations result in 415170 HUF ha- ${ }^{-1}$ additional production costs.

The difference between the extra revenues and the additional costs points out, that the establishing of hail protection nets increases the annual profit, more precisely, the annual cash flow by 794333 HUF.

The profitability of hail protection nets shows a very positive image. The additional costs of hail protection net investment return over 5 years even in case of $100 \%$ own financing sources. With investment support, the payback period is reduced to 3 years. Every economic indicator can be considered as very positive.

If the yield increasing potential of higher trees is not utilised, the economic indicators decrease significantly, but remain still acceptable. The investment payback period without support was delayed to 8-10 years, which is not very good, but still a reasonable value. The presence of investment support provides good values in this case as well.

It can be concluded, that the installation of hail protection nets as additional technological element of intensive apple orchards can be concluded by all means as an economic investment - trough their protective effect. However, to achieve really favourable economic indicators, definitely bigger tree height is needed making possible the realisation of around $8.0 \mathrm{t} \mathrm{ha}^{-1}$ extra yield. The main root of this phenomena are obviously the extremely high investment costs of hail protection nets, which result in a large mass of fixed costs during the production period. Therefore the basic economic interest is reaching higher yields and thereby higher profits per unit area. 


\section{REFERENCES}

Apáti, F. (2009): The comparativeeconomicanalysis of Hungarian and Germanappleproduction of good standard. Internationa Journal of Horticultural Science. 15. 4: 79-85.

Apáti F. (2012): Gyümölcsültetvények fagy- és jégvédelmének technológiai lehetőségei és gazdasági megfontolásai. Debreceni Egyetem AGTC Kertészettudomány Intézet. Debrecen. 227.

Apáti F.-Gonda I. (2013): Almatermesztésünk helyzete és kilátásai. [In: Gonda I.-Apáti F. (szerk.) Versenyképes almatermesztés.] Szaktudás Kiadó Ház. Budapest. 15-22.

Brealey, R. A.-Myers, S. C.-Allen, F. (2006): Corporate Finance (Eight Edition). McGraw-Hill. 84-143., 244-272.

Fruitveb (2013): Apple. Fruit and Vegetable Report. Fruit Veb Hungarian Interprofessional Organisation for Fruit and Vegetables. Budapest. 16-17.

Graham, J. R.-Harvey, C. R. (2001): The Theory and Practice of Finance: Evidence from the Field. Journal of Financial Economics. 61 187-243.
Illés M. (2002): A beruházások gazdaságossága. [In: Illés M. (szerk.) Vezetői gazdaságtan.] Kossuth Kiadó. Budapest. 115-162.

KSH (2013): http://www.ksh.hu

Lakner, Z.-Apáti, F. (2010): Economics of apple-storage I. Comparative time series analysis of apple producer prices in Germany and Hungary. International Journal of Horticultural Science. 16. 4: $75-79$.

Szőllősi L. (2008): A vágócsirke termékpálya 2007. évi költség és jövedelem viszonyai. Baromfi Ágazat. 8. 4: 4-12.

Szűcs I.-Szőllősi L. (2008): A beruházások ökonómiai megítélése [In: Nábrádi A. et al. (szerk.) Üzemtan I.] Szaktudás Kiadó Ház. Budapest. 46-59.

Warren, M. F. (1982): Financial Management for Farmers, the Basic Techniques of 'Money Farming' (Third Edition). Stanly Thornes Ltd. 240-246., 259-260.

Z. Kiss L. (2003): A gyümölcstermesztés feltételrendszere. [In: Z Kiss L. (szerk.) A gyümölcstermesztés, -tárolás, -értékesítés szervezése és ökonómiája.] Mezőgazda Kiadó. Budapest. 13. 
